\title{
National COVID-19 lockdown exit strategies need to pay more attention to community engagement and workplace safety
}

\author{
Kathrin Cresswell ${ }^{1}$, Sangeeta Dhami ${ }^{2}$, Aziz Sheikh ${ }^{1}$
}

\footnotetext{
${ }^{1}$ Usher Institute, The University of Edinburgh, UK

${ }^{2}$ GP Locum, Edinburgh, UK
}

The World Health Organization (WHO) issued a checklist of six lockdown exit criteria but many (particularly high-income) countries do not sufficiently consider these when making decisions on existing lockdowns. he emergence of SARS-CoV-2 in December 2019 has resulted in the unprecedented lockdown of over 4.5 billion people globally in an attempt to reduce virus transmission, infection and death rates, and to protect health care systems [1]. However, with concerns mounting regarding the unintended health (eg, through disruption to immunisation programmes), societal (eg, mental health) and economic effects of lockdown, there is mounting pressure in many countries to relax lockdown measures [2]. A clear decision making framework should guide these vitally important national/regional decisions.

In April 2020 the World Health Organization (WHO) issued a checklist of six lockdown exit criteria for countries to consider (Box 1) [3]. Our analysis has however found that many (particularly high-income) countries have chosen to formulate their own criteria, which do not always align with the WHO criteria (Table 1). These divergent approaches may reflect the limited traction that WHO has in many high-income countries, the speed and form of the initial response, and as a result, very different rates of infection. They may also reflect different stages of the pandemic that countries find themselves in and available health and other resources to respond to the challenges thrown up by COVID-19 [21,22].

Our analysis has identified areas of broad agreement in relation to controlling community transmission, adequate health care capacity, and detecting and isolating cases (WHO Recommendations 1 and 2, Table 1). The most common measurement criterion used internationally is the reduction of cases, but there is a lack of agreement of what precisely this reduction should be and countries have as a result developed different indicators. Examples include "new coronavirus infections stabilise at a low level" (Germany), "infection rates decreasing to manageable levels" (United Kingdom), or "sustained reduction in cases" (Canada). An exception is Singapore, which clearly states "bring down daily infections more sharply, to single digit, or even zero". The most commonly used measurement is a reduction in reproduction rate, $\mathrm{R}_{\mathrm{t}}$, to below 1 .

Areas of divergence mainly relate to WHO Recommendations 3-6, concerning preventative measures for curbing spread in vulnerable communities and in workplaces, and the need for sustained community engagement. The lack of attention to prioritising highly vulnerable communities is of concern given that, for example, almost half of COVID-19 deaths in Europe have occurred in care homes [23]. 
Box 1. WHO lockdown exit criteria.

1. COVID-19 transmission is controlled to a level of sporadic cases and clusters of cases, all from known contacts or importations; at a minimum, new cases would be reduced to a level that the health system can manage based on health care capacity.

2. Sufficient public health workforce and health system capacities are in place to enable the major shift from detecting and treating mainly serious cases to detecting and isolating all cases, irrespective of severity and whether there is local transmission or an importation.

3. Outbreak risks in high-vulnerability settings are minimised, which requires all major drivers or amplifiers of COVID-19 transmission to have been identified, with appropriate measures in place to maximise physical distancing and minimise the risk of new outbreaks.

4. Preventive measures are established in workplaces.

5. Manage the risk of exporting and importing cases from communities with high risks of transmission.

6. Communities are fully engaged and understand that the transition away from large-scale movement restrictions and public health and social measures - from detecting and treating serious cases to detecting and isolating all cases - is a 'new normal' in which prevention measures would be maintained, and that all people have key roles in preventing a resurgence in case numbers.

Table 1. International lockdown exit criteria mapped to WHO recommendations

\begin{tabular}{|c|c|c|c|c|c|}
\hline WHO RECOMMENDATION & $\begin{array}{l}\text { Recommendation 1: } \\
\text { Controllng Community } \\
\text { transmission }\end{array}$ & $\begin{array}{l}\text { Recommendation 2: } \\
\text { HealthCare capacity }\end{array}$ & $\begin{array}{l}\text { Recommendation 2: } \\
\text { Detecting and isolating } \\
\text { cases }\end{array}$ & $\begin{array}{l}\text { Recommendation 3: } \\
\text { MinIMISE OUtBReAKS IN } \\
\text { HIGH VULNERABILTY SEtTINGS }\end{array}$ & $\begin{array}{l}\text { Recommendation 3: Maximise } \\
\text { PHYSICAL DISTANGIIGG AND MINIIIISE } \\
\text { THE RISK OF NEW OUTBREAKS }\end{array}$ \\
\hline Austria [4] & $\times$ & & & & \\
\hline Czech Republic [5] & $x$ & & & & \\
\hline Denmark [6] & $x$ & & & & \\
\hline France $[7,8]$ & $x$ & & & & \\
\hline Ireland [9] & $x$ & $x$ & $x$ & $x$ & \\
\hline Scotland [10] & $x$ & $x$ & $x$ & & $x$ \\
\hline Spain [11] & $x$ & $x$ & & & $x$ \\
\hline Italy [12] & $x$ & & & & \\
\hline Belgium [13] & $x$ & & & & \\
\hline United Kingdom [14] & $x$ & $x$ & $x$ & & \\
\hline Germany [15] & $x$ & $x$ & & & $x$ \\
\hline Singapore [16] & $x$ & & & & \\
\hline New Zealand $[17,18]$ & $x$ & $x$ & $x$ & & $x$ \\
\hline Australia [17] & & $x$ & & & \\
\hline United States [19] & $x$ & $x$ & $x$ & & \\
\hline Canada [20] & $x$ & $x$ & $x$ & & \\
\hline
\end{tabular}

WHO - World Health Organization

Criteria around community engagement and workplace safety have been neglected in many responses to the pandemic's first wave and now need to inform policy formulation on exit strategies going forward.
Recommendation 5, tackling preventative measures in workplaces, is not mentioned in any lockdown exit criteria. This seems to be despite major concerns in the community. For example, Scotland's Health and Safety Executive has already received 390 public concerns regarding workplace safety since March 2020, prior to any easing of lockdown measures [24].

Of note is also that, currently no country has included WHO Recommendation 6 in their lockdown exit criteria, aiming to ensure that communities understand public health prevention measures and take them seriously as they move to collectively contain transmission and mitigate the effects of the pandemic.

These medium- to long-term deliberations are crucial to ensuring the sustainability of managing the pandemic and should therefore be considered necessary conditions for exiting lockdown. These factors have an impact on community transmission and therefore play an important role in influencing overall success 


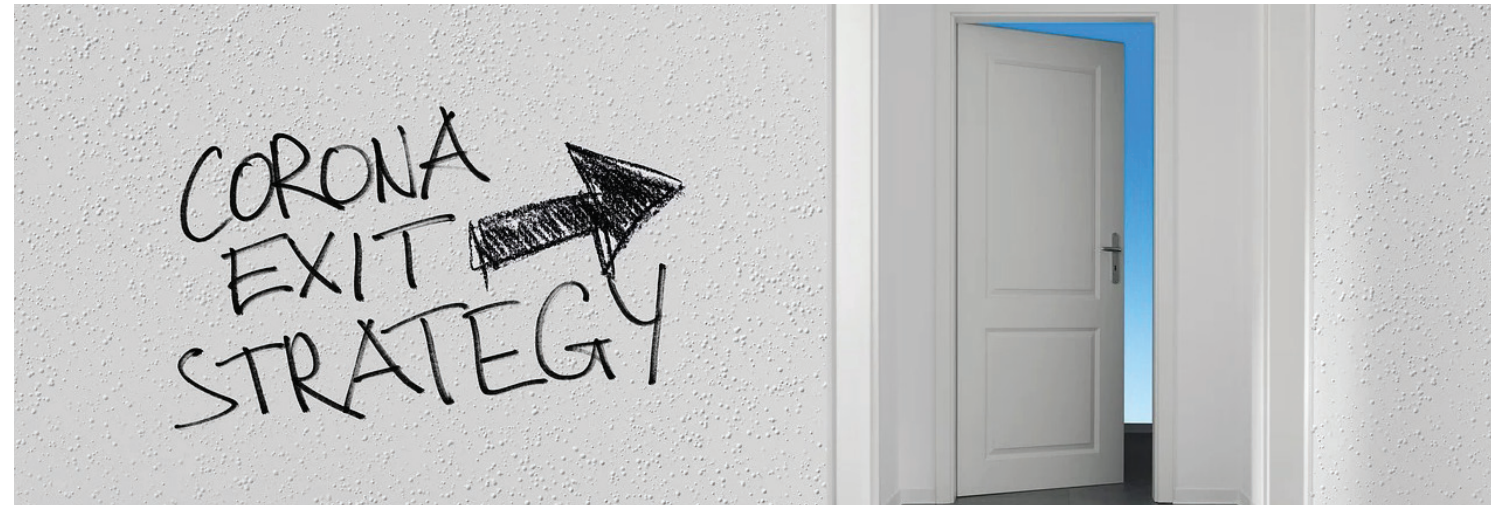

Photo: https://cdn.pixabay.com/photo/2020/04/14/05/59/door-5041047_1280.jpg.

of strategies. For example, in order to effectively implement test, trace, and isolate measures, the public will need to understand that they may have to share some of their personal data to allow adequate contact tracing, an issue some - particularly those living in Western liberal democracies - may perceive as an infringement of civil liberties. Similarly, to keep the transmission rate low, the public will need to continue to implement and respect measures surrounding physical distancing in all settings including the workplace and social gatherings.

Overall, our analysis shows that as countries move from the containment phase to longer-term thinking, there is a need to place greater emphasis on meaningful dialogue with the public to co-formulate sustainable engagement strategies and to avoid confusion and non-compliance to lockdown easing [25,26].

Our analysis will, we hope, allow countries to take stock of the range of approaches that they have employed thus far and help to refine their lockdown exit criteria by incorporating the need for genuine community dialogue and engagement. This will be imperative if countries are to develop a shared understanding of the 'new normal'. It is hoped that early experiences and lessons will also be proactively shared between member nations through the WHO [27].

Funding: None to report.

Authorship contributions: AS conceived this paper. KC and SD led the drafting of the manuscript and all authors commented on drafts of the manuscript.

Competing interests: The authors completed the ICMJE Unified Competing Interest form (available upon request from the corresponding author), and declare no conflicts of interest.

1 Coronavirus pandemic: Tracking the global outbreak. Available: https://www.bbc.co.uk/news/world-51235105. Accessed: 29 June 2020.

2 World Economic Outlook, April 2020: The Great Lockdown. Available: https://www.imf.org/en/Publications/WEO/Issues/2020/04/14/weo-april-2020. Accessed: 29 June 2020.

3 Considerations in adjusting public health and social measures in the context of COVID-19. Available: https://apps.who. int/iris/bitstream/handle/10665/331773/WHO-2019-nCoV-Adjusting_PH_measures-2020.1-eng.pdf. Accessed: 29 June 2020.

4 Coronavirus Exit Strategy: Austria To Ease Lockdown, Successful Transition Would Underpin Euro Sentiment. Available from: https://www.exchangerates.org.uk/news/29151/2020-04-07-coronavirus-exit-strategy-austria-to-ease-lockdown-successful-transition-would-underpin-euro-sentiment.html. Accessed: 29 June 2020.

5 Czechs ease lockdown, but extend state of emergency. Available: https://www.aljazeera.com/news/2020/04/czechs-easelockdown-extend-state-emergency-200424191907914.html. Accessed: 29 June 2020.

6 Denmark to ease restrictions next week after coronavirus lockdown. Available: https://uk.reuters.com/article/uk-health-coronavirus-denmark/denmark-to-ease-restrictions-next-week-after-coronavirus-lockdown-idUKKBN21O2LD. Accessed: 29 June 2020.

7 France announces 'progressive and controlled' lockdown exit plan. Available: https://www.theguardian.com/world/2020/ apr/28/france-and-spain-announcement-lockdowns-ease. Accessed: 29 June 2020. 
810 key points that will drive France's exit out of coronavirus lockdown. Available: http://www.rfi.fr/en/france/20200429france-government-plan-lifting-coronavirus-covid-confinement-lockdown-masks-tests-schools-bars-restaurants. Accessed: 29 June 2020.

9 Leo Varadkar identifies five key criteria for easing Ireland's lockdown restrictions in future. Available: https://www.irishpost.com/news/leo-varadkar-identifies-five-key-criteria-easing-irelands-lockdown-restrictions-future-184433. Accessed: 29 June 2020 .

10 Coronavirus (COVID-19): framework for decision making. Available: https://www.gov.scot/publications/coronavirus-covid-19-framework-decision-making/. Accessed: 29 June 2020.

11 Spain details four-phase plan to ease lockdown. Available: https://www.rte.ie/news/coronavirus/2020/0429/1135574spain-details-four-phase-plan-to-ease-lockdown/. Accessed: 29 June 2020.

12 Coronavirus: Italy's PM outlines lockdown easing measures Available: https://www.bbc.co.uk/news/world-europe-52435273. Accessed: 29 June 2020.

13 Belgium eyes extension of lockdown measures. Available: https://www.politico.eu/article/belgium-eyes-extension-of-lockdown-measures/. Accessed: 29 June 2020

14 Coronavirus: UK lockdown extended for 'at least' three weeks. Available: https://www.bbc.co.uk/news/uk-52313715. Accessed: 29 June 2020.

15 Germany's coronavirus lockdown exit plans: What happens now? Available: https://www.thelocal.de/20200414/germanys-coronavirus-lockdown-what-happens-now. Accessed: 29 June 2020.

16 Singapore Pledges \$2.7 Billion More, Virus Measures Extended. Available: https://www.bloomberg.com/news/articles/2020-04-21/singapore-extends-partial-lockdown-measures-until-june-1. Accessed: 29 June 2020.

17 The exit strategy: how countries around the world are preparing for life after Covid-19. Available: https://www.theguardian.com/world/2020/apr/19/the-exit-strategy-how-countries-around-the-world-are-preparing-for-life-after-covid-19. Accessed: 29 June 2020 .

18 Covid 19 coronavirus: Jacinda Ardern's lockdown decision today despite contact-tracing being short of 'gold standard'. Available: https://www.nzherald.co.nz/nz/news/article.cfm?c_id=1\&objectid=12325895. Accessed: 29 June 2020.

19 National coronavirus response: A road map to reopening. Available: https://www.aei.org/research-products/report/national-coronavirus-response-a-road-map-to-reopening/. Accessed: 29 June 2020.

20 What will Canada's Pandexit strategy look like? How officials are deciding when to lift coronavirus lockdowns. Available: https://www.theglobeandmail.com/canada/article-what-will-canadas-pandexit-strategy-look-like-how-officials-are/. Accessed: 29 June 2020.

21 Sohrabi C, Alsafi Z, O'Neill N, Khan M, Kerwan A, Al-Jabir A, et al. World Health Organization declares global emergency: A review of the 2019 novel coronavirus (COVID-19). Int J Surg. 2020;76:71-6. Medline:32112977 doi:10.1016/j. ijsu.2020.02.034

22 Opinion - Coronavirus. A Global Crisis Waiting for a Global Response. Available: https://www.e-ir.info/2020/04/02/ opinion-coronavirus-a-global-crisis-waiting-for-a-global-response/. Accessed: 29 June 2020.

23 Coronavirus: Care homes could be where over half of Europe's COVID-19 deaths occur, says new study. Available: https:// www.euronews.com/2020/04/17/coronavirus-care-homes-could-be-where-over-half-of-europe-s-covid-19-deaths-occursays-new. Accessed: 29 June 2020.

24 Coronavirus: Safety watchdogs deal with hundreds of workplace complaints. Available: https://www.bbc.co.uk/news/ uk-scotland-52693243. Accessed: 29 June 2020.

25 Coronavirus: Boris Johnson accepts 'frustration' over lockdown rules. Available: https://www.bbc.co.uk/news/uk52694623. Accessed: 29 June 2020.

26 Coronavirus: Unions and city mayor defy government's call to reopen schools. Available: https://news.sky.com/story/ coronavirus-union-attacks-govt-plan-to-reopen-schools-on-1-june-after-crunch-meeting-11989045. Accessed: 29 June 2020.

27 COVID-19 response. Available: https://apps.who.int/gb/ebwha/pdf_files/WHA73/A73_CONF1-en.pdf. Accessed: 29 June 2020. 